\title{
The Mediatized Conditions of Contemporary Religion: Critical Status and Future Directions
}

\author{
Mia Lövheim \\ Uppsala University \\ mia.lovheim@teol.uu.se \\ Stig Hjarvard \\ University of Copenhagen \\ stig@hum.ku.dk
}

\begin{abstract}
During the last decade the framework of mediatization theory has been introduced in the field of media, religion and culture as a parallel perspective to the "mediation of religion" approach, allowing new questions to be posed that align with religious change within Europe. This article provides a critical review of existing research applying mediatization of religion theory, focusing on key issues raised by its critics as well as how the theory have moved the research field forward. These issues concern the concept of religion, institution and social change, religious authority, and the application of mediatization theory outside the North-Western European context where it originated. The article argues that an institutional approach to mediatization is a relevant tool for analyzing change as a dynamic process in which the logics of particular forms of media influence practices, values and relations within particular manifestations of religion across various levels of analysis.
\end{abstract}

\section{Keywords}

mediatization - religion - institution - change - new institutionalism - theory 


\section{Introduction}

The relationship between increased technological mediation since the 2oth century and religious change has been at the forefront of the study of media, religion and culture since the beginning of the research field. Stewart Hoover and Knut Lundby (1997) outlined an agenda for the field that aimed to overcome a linear and deterministic approach to social and cultural change which, they argued, dominated previous research in religious studies and in media and communication studies. A new approach was needed that challenged narrow conceptualizations of religion, as located in propositional beliefs and particular organizations, and of media, in terms of the production and "effects" of messages. Research in the new field should start from an understanding of media as "the site of the synthesis and symbolism of culturally meaningful belief systems" (Clark \& Hoover, 1997, p. 17), and from an understanding of religion as meaning making located in people's everyday life experience. This "mediation approach" was inspired by the "culturalist turn" in media studies, as in much of the humanities and social sciences, at the end of the 1980 (Hoover, 2002).

Some 30 years later, the humanities and social sciences are facing new challenges. Research on contemporary religious change, at least from a European perspective, has focused on the heightened visibility of religious diversity following from increased globalization and migration from the African continent and the Middle East. The presence of religions other than the Christian churches that historically dominated European societies has generated new forms of political conflict and state governance of religion (Hjelm, 2015). In particular, proponents of the populist parties impel polarization between Islam, framed as a threat towards national culture and democratic values, and Christianity, selectively embraced as a civilizational identity (Brubaker, 2017, p. 14). At the same time, the general trend of membership and activity among Christian Churches and denominations in Western Europe is a slow but continuing decline. While these tendencies might be more pronounced in Western Europe, similar processes are visibly present in the US, the Russian Federation, the Middle East and Asia. As argued by Furseth (2018), this situation of increased "religious complexity" calls for theories that can assess the presence of multiple, parallel and seemingly contradictory trends of religious change.

Mediatization theory has been introduced over the last decade as a new perspective in understanding the role of the media for religious and social change (Lundby, 2018b; Lövheim, 2014). Within media studies, the mediatization agenda grew out of a need to fully capture the significance of the ubiquitous presence of both mass media and newer forms of digital and interactive media for the performance of many social and cultural activities (Livingstone, 2009). 
Building on a first wave of mediatization studies primarily looking at the mass media's restructuring of politics (Asp, 1990), a second wave of studies broadened its scope to think of mediatization as a concept referring to the "long-term interrelation processes between media change on the one hand and social and cultural change on the other" (Hepp, Hjarvard, \& Lundby, 2010, p. 223). As various forms of media became "part of the very fabric" of culture and society (Hepp, Hjarvard, \& Lundby, 2010, p. 223), a perspective is needed that addresses how particular instances of mediated communication relate to broader, institutional logics and structural changes within and between societal domains.

The aim of this article is to review discussions within the field of media, religion and culture in the last decade about the validity of mediatization theory for understanding a situation of simultaneous visibility, contestation, and decline of religion in public life. We argue that, in order to address this situation, research on media and religion needs to focus on the interplay between religious and other social institutions, and how various forms of media function as intermediaries for processes of change within and between these domains. This situation calls for a renewed discussion of how institutions form the conditions for social interaction and meaning making, and how this affects changes in the role of religion for individuals and in society.

\section{Mediatization of Religion Theory: Critique and Contribution}

The use of mediatization theory to analyze religious change was introduced to media, religion and culture research through the work of Stig Hjarvard (2008; $2011 ; 2013$ ). During the last decade, the theory has been developed in the Scandinavian setting through a series of research projects and books (Hjarvard \& Lövheim, 2012; Lövheim, 2014; Lundby et al., 2018; Lundby, 2018a; Moberg, 2018).

Mediatization theory applied to religion refers to the processes "through which religious beliefs, agency, and symbols are becoming influenced by the workings of various media" (Hjarvard, 2016, p. 8). Mediatization of religion as a theory seeks to analyze how changes in religion take place both at the structural level, meaning the relation between media and religion as institutional domains in society, and at the level of social interaction, as expressed within particular organizations and in the practices of individuals.

The introduction of the mediatization of religion as a parallel perspective to the mediation approach generated ongoing debates among researchers in the field (for an overview see Lövheim, 2014; Lövheim \& Lynch, 2011). Some of the claims of the theory have been widely embraced in these debates, for example that the media has become the primary site for the circulation of religious symbols in contemporary society, and that this contributes to a wider 
circulation of popular and individualized elements of religion. Some of the premises and claims of the theory, however, have been severely criticized. In the following we will discuss in particular four themes that have been central in debates about the theory of the mediatization of religion. We will also show how recent developments of the theory can contribute to moving the research field forward. We will focus on the conceptualizations of religion, of institutions and of social change within the theory, and illustrate how these concepts can be useful for understanding the changing foundation of religious authority in late modern, North-Western European societies where the theory originated. Finally, we will discuss how these concepts might be valid for analyzing changes in other religious and societal contexts.

\section{3} Religion and Religious Change

The mediatization of religion theory was formulated as a response to some problems regarding the application of a mediation approach in studying and assessing religious change. As argued by Hjarvard (2008; 2011), the understanding of religion as "culturally meaningful belief systems" (Clark \& Hoover, 1997, p. 17) complicates an analysis of how mediation shapes the particularities of religious beliefs, practices and organizations as forms of meaning making and social interaction. Furthermore, the focus on particular situations and individual actors did not provide analytical tools to address change over time, or relations between media and religion as social institutions, for example with regard to social influence and authority.

Critique of the conceptualization of religion within the mediatization of religion theory has mainly been expressed by scholars within religious studies and anthropology (see Lövheim, 2011; 2014, for a summary of the debate). Lövheim (2011, pp. 154-5) has pointed out that the theory focuses on relations between religion and media at a meso-level, and primarily discusses religion as a "sacred canopy," an overarching and coherent system of meaning making in society (Lövheim, 2011, p. 155). From this perspective, the impact of mediatization becomes a weakening of religion. When media becomes the primary site for public engagement with religion, the role of religious organizations and authorities to control the use and meaning of symbols among believers is reduced. Hjarvard's main point here is that, in the long run, the reproduction of religion in society becomes more diffuse and volatile when it increasingly becomes dependent on the agency of media and other institutional agents rather than on established and regulated forms of religion, such as state churches (Hjarvard, 2011; 2016).

Another key point in the critique has been that transformations of religion, including the weakening of collective forms of religion, do not make 
religion "less religious." As argued by Meyer (2013), among others, mediation and re-mediation are intrinsic characteristics of religion. This implies that transformations of religion due to mediation need to be analyzed as situated within already existing mediation practices of a religion. Furthermore, religious groups have throughout history made use of modern media technology to present their message in the public sphere (Horsfield, 2013; Morgan, 2011).

There has also been criticism of the term "banal religion" in Hjarvard's early presentations of the theory, referring to the mix of elements from organized religions and popular beliefs circulated through the media (Axelson, 2015; Lied, 2012). This argument by Hjarvard $(2008 ; 2011)$ was inspired by Billig's (1995) similar notion of "banal nationalism", and was meant to draw attention to the taken-for-granted character of many ideas about religion. Such "banal" forms of religion may appear illegitimate by established religious authorities, but they constitute an important backdrop for many people's ideas about what constitutes "the religious." Thus from Hjarvard's point of view the term "banal" does not imply insignificance or lack of legitimacy.

A final point of critique against the understanding of religion in early versions of mediatization of religion theory has been that it overlooks the agency of religious actors to adapt to or resist the ways in which the meaning of symbols or relations between organization and individuals become influenced by various media (Clark, 201b; Lövheim, 2011).

\section{New Perspectives on Institutions}

Hjarvard's approach to the theory of mediatization has been characterized as "institutional" and primarily focusing on the "structuring influence" of the logics of media institutions for social interaction within other domains of society (Hepp, 2013, p. 42; Hjarvard, 2008; 2014, p. 127). As we will argue in the following, at least some of this critique stems from differing interpretations of the concept of institution and how this captures the dynamic between individual agency and social structure in social change.

Lynch (2011) argues that a certain degree of institutionalization of both religion and media is needed in order for some of the main arguments of Hjarvard's early versions of the thesis to be relevant. The Nordic and North-Western European countries are characterized by a high degree of institutionalization, as expressed by a clearly identifiable religious institution in the shape of national majority churches (in some cases, state churches) and by strong media institutions with a non-confessional orientation such as public service media or daily newspapers. What is more, in these countries state regulations and 
subsidiaries provide an institutional structure for the role that religious organizations and media providers play in society, as well as the relations between them. Lynch argues that the explanatory power of mediatization theory loses validity when applied to a context where both religion and media do not display this kind of strong institutionalization.

Herbert (2011) points out that, although similar structural changes with regard to increasing media presence and impact can be observed on a global scale, the implications of such changes for religious organizations, and for the relation between them and various media providers, will differ between "western," "post-colonial" or "post-communist" societies. In countries such as Egypt, individual use of "small media," such as audio- and videocassettes and CDs, has been important for transformations of religious communication and authority, rather than changes within established media institutions (Sreberny-Muhammadi \& Muhammadi, 1994). When studying forms of religion that are largely practice-oriented and based on local tradition, such as Vodou, a theory that starts out from an institutional perspective on media and religion becomes even more difficult to apply (see for example Boutros, 2011). These examples show that, in order to be valid, an institutionally oriented analysis of mediatization of religion needs to start out from the ways in which religion and media as social entities are organized in a particular context, and how historical as well as wider social structures and processes affect both media and religion as institutions.

While recognizing this situation, we do not, however, agree with the suggestion by Hoover $(2009$, pp. 135, 136) that mediatization research should look "beyond and below the levels" of large scale contexts and institutions in order to develop more "complex, nuanced, and layered" understandings of the interplay between media, religion and culture. Lynch's argument (2011) raises the question of the validity of an institutional perspective depending on the empirical context, while Hoover's argument seems to question whether an institutional perspective can be sensitive towards the level of cultural practices and human agency. In the following we will address both the question of how an institutional perspective can be relevant outside a particular context of strong institutions, such as the Nordic countries, and how it can include aspects of human agency, culture and religion.

Institutional theory, and in particular the development of this theory that is termed "new institutionalism," has a stronghold in Nordic social science (e.g. Engelstad et al., 2017; March \& Olsen, 1989). Starting from this strand of theory, we would like to make a few points of clarification. First, institutions are, conceptually speaking, not to be confused with organizations. An institution is a framework for action that regulates the structuring of resources (material and 
symbolic) and rules (formal and informal) within a larger social and cultural context (Engelstad et al., 2017, p. 3). An institution can be more or less formalized through agreements, rules or legislation that have a long-term character. However, institutions are not per se located at a particular level in social structure. Institutions must be enacted by some aggregate of actors in society, such as organizations. Institutions can, furthermore, be specified on various levels of organization, such as "the daily press" and the "local newspaper" (Lundby, 2017).

Our second point concerns widening the scope of explanatory factors for analyzing how institutions work and how they may change. As argued by DiMaggio and Powell (1991, p. 8), a core idea of new institutionalism is to reject "rational-actor models" and functionalist explanations, and turn to "cognitive and cultural explanations." Agency in a group or community cannot only be conceptualized as maximizing individual interests but also as an outcome of the "ethos, practices and expectations" of the institutional context (March \& Olsen, 2004, p. 3). Thus, we need to take into account how norms and actions at both collective and individual levels are implicated in continuous processes of reflexive sense-making in relation to the context. According to March and Olsen (2004), a "logic of appropriateness" is applied in collective and individual agency and what is appropriate is also a matter of cognition and cultural interpretation. Thornton and Ocasio (1999, p. 804) define, accordingly, institutional logics as the "socially constructed, historical pattern of material practice, assumptions, values, beliefs, and rules by which individuals produce and reproduce their material subsistence, organize time and space, and provide meaning to their social reality." In sum, "new institutionalism" provides a framework for an understanding of institutions that takes into account the social construction of meaning and the role of symbols and values, as well as how the particular "logics" of an institution are created and negotiated through human agency (see Hjarvard, 2014).

Our third point concerns how newer forms of institutional theory enable us to analyze the dynamics of institutional change with regard to how institutions overlap or intersect with each other. These aspects are particularly relevant for addressing how mediatization of religion is informed by the interrelationships between particular institutional forms of media and religion and wider social and cultural transformations (Herbert, 2011). Neither religion nor media can be understood as self-contained entities governed by their inner institutional logics. Broadcast media, for instance, have a different institutional history in the Nordic countries, United States and Southern Europe due to the ways media have interacted with other institutions such as politics, religion, the family, the educational system, etc. In a similar vein, religion, from an institutional perspective, is not a unitary phenomenon but constructed through the ways in which various collective and individual actors historically and in particular 
situations enact understandings about what religion is and how it should be practiced (see Lövheim \& Lied, 2018). This means that all manifestations of a religious tradition, such as Christianity, are institutionalized, but the degree of formalization and regulation of the institution is an empirical question.

As pointed out above, the mediatization of religion theory has been criticized for applying a deterministic understanding of change, for example in arguing for a general trend where the reduced influence of religious organizations on a societal level leads to the marginalization of religion in motivating collective as well as individual beliefs, lifestyle and action (Couldry, 2008). The notion of "change" is central to mediatization theory and it is therefore important to clarify the meaning of this notion. Change in mediatization theory involves two interrelated aspects. The first concerns a reconfiguration of the relationships between media, religion and other societal domains with regard to influence in society, and the second concerns changes in the conditions of communication and interaction in society. The fact that these aspects are interrelated in different and complex ways was present in early versions of mediatization theory (Hjarvard, 2008), and has been even more emphasized in recent applications.

A perspective that emphasizes the dynamic between media and religion as institutions means that neither the affordances of individual media nor the overall media system determines processes of mediation, but they influence the scope and forms of communicative agency in various ways. Thus, mediatization can become visible through certain ruptures that introduce new ways of acting, or through particular events where accumulated tensions between social actors and institutional domains are released into a full-blown conflict.

Such conflicts may in themselves stimulate further mediatization at the same time as the courses of conflicts are influenced by various media dynamics. The Charlie Hebdo events in France in 2015 (see Hjarvard \& Lundby, 2018) or the Muhammed cartoon crisis in 2006 (Hjarvard, 2006) can serve as examples. The mediatized conditions of contemporary society insert a series of dynamics into events through which the media may work as amplifiers of conflict, frame conflicts in particular ways, and provide a series of stages upon which the conflicts are performed. On a structural level, the media environment may co-structure developments by setting conditions for access and voice of the conflicting parties (Hjarvard, Mortensen, \& Eskjær, 2015). Media do not determine the course of events but they may influence conflicts in various ways and are often criticized by various involved actors for escalating conflicts and 
stereotyping actors and issues. Such consequences are clearly prominent in many conflicts, but the dynamics of the media may also serve other ends under conflictual circumstances.

Mediatization may, however, also be a slow, evolutionary type of change which only becomes visible through historical comparison over a wider stretch of time. The influence of the press, radio and television, the internet, and social media may accumulate over time but their influence on other social and cultural domains may vary significantly in different periods. This approach leaves it open to empirical studies to see if and how religion at macro, meso and individual levels are linked, the intensity of those links, and possible mutual adaptations and change. Lundby's (2016) study of the history of public religion in Norway shows how change can be analyzed in this way.

This understanding of change aligns with the "religious complexity" approach proposed by Inger Furseth (2018) in order to analyze seemingly contradictory developments characterizing religion in the Nordic countries. Our institutional perspective on mediatization shares with complexity theory the conceptualization of social structures as consisting of overlapping and mutually affecting social relations. This understanding of social change seeks to "keep the notion of systematic inter-relatedness, while yet not pre-specifying, in a rigid way, the nature of these interconnections" (Walby, 2007, p. 459).

The aim of mediatization theory is thus to conceptualize "change" within a holistic perspective that allows us to analyze processes of change by looking at the interplay between structure and agency at various levels of analysis, i.e. macro, meso, and micro levels. In practice, few studies published within the typical journal article format are able to fulfil such an ambition. Therefore, many studies of the mediatization of religion have predominantly looked at structural change at organizational levels or at agency at micro levels. Nevertheless, the ambition to situate micro levels of analysis within an understanding of larger transformations and, vice-versa, to qualify and nuance macro level analysis through empirical findings also at the meso and micro levels is important to substantiate a holistic perspective in empirical research.

The Scandinavian study Engaging with conflicts in mediatized religious environments (Lundby, 2018a) is one example of a large research project that integrates various levels of analysis by combining different methodologies (surveys, observation, qualitative and quantitative content analysis, etc.) within specific sub-areas of enquiry: conflict over religion in public service media, within local, civil society settings, and in upper-secondary schools. Studies within the project also show how religious actors and media producers (Hjarvard \& Rosenfeldt, 2017) are able to consciously use the media to engage with contentious issues in ways that may reduce ethnic and religious stereotypes, 
polarization, etc. On the basis of such findings, Lundby argues (Lundby 2018b) that audience activity and other forms of civic participation must be seen as an integral part of mediatization processes.

The role of media in changing religious authority shows where an institutional perspective on mediatization can become fruitful. The growing influence of various forms of media implies the emergence of new conditions concerning the authority to speak about religion but also new institutional resources from which authority may be claimed (Hjarvard, 2016). Meyer and Moors (2006, p. 11) suggested that the media "shape the specific modes by which religions go public, modes that are difficult to control by the religious establishment." Herbert (2011) argues that mediatization contributes to the loosening of ties between religious symbols and discourses and particular religious communities. Following this, he argues, we need to distinguish between "the religious" as an institution in the form of representations and practices circulating in society and particular manifestations of "religion" through specific organizational beliefs and practices.

Campbell $(2007 ; 2010)$ documented how changes of authority may affect several dimensions of religion as institution, such as hierarchy, structure, ideology, and text. Her discussion is based on Weber's (1978) distinction between three ideal types of authority: traditional, charismatic, and rational-legal. An institutional perspective on mediatization can further clarify how particular sources for religious authority become influenced by the workings of particular media institutions. Journalism may predominantly subscribe to a rational-legal form of authority. Studies of news media's coverage of religion in Scandinavia bear witness to the fact that a secular framing of religion is dominating, informed by professional journalistic news values (Christensen, 2012). Religious arguments do not exert strong authority in editorials (Lövheim, 2017), or on the opinions pages in Scandinavian newspapers, and religious representatives tend to use secular arguments, for example by reference to science, humanism, or values of freedom and equality (Axner, 2013).

Clark $(2008$; 2011a) has demonstrated how popular media formats (e.g. the TV series LOST) and social actors outside established religious communities (e.g. talk-show host Stephen Colbert) have gained authority to speak and inform public discourse on religious issues in an American context. She suggests the notion of a "consensus-based interpretative authority" in order to capture how such mediated forms of authority rely on the criteria of popularity and 
consensus within a media-user network. These examples can deepen an analysis of what Weber termed charismatic forms of authority that capture what is at play in these contexts through focusing on institutional dynamics of entertainment media.

The spread of interactive digital media technology paves the way for other ways of establishing authority. To establish online authority, you may build on various institutional resources (e.g. of a political, scientific, or religious nature) but you also rely on your ability to demonstrate a sensibility and attentiveness to your followers' perceptions and emotions. On the surface, online authority may appear to be much more individualized and distributed, perhaps even more democratic, compared to centralized authority within different forms of organizations.

An institutional perspective enables an analysis that reveals how newer online types of authority are also socially structured, including being structured by the media system. As van Dijck (2013) has emphasized, social network media are driven by various logics based on their technological (e.g. algorithms) and economic structure (e.g. business model), so what appears as a personal choice or recommendation is also informed by data-driven connections and economic incentives.

The intersection of mediatization, gender and religion is an area where this complexity comes to the fore. Studies of young Muslim women's attempts to build a more independent voice in a Nordic context (Lövheim, 2012; 2016) and of Evangelical lay women's use of personal blogs to discuss the application of religious teachings in everyday life (Klassen \& Lofton, 2013) show that digital media provide new possibilities for women to perform previously "male" coded, authoritative roles, such as giving ethical advice or interpreting sacred scriptures. However, although social network media might benefit forms of religious authority based on personal experiences, and the ability to connect these with the concerns of others, the logic of these media also brings new challenges and forms of social control, such as critical comments (Lundmark, 2019). An individual's ability to solidify authority over time and space therefore depend on her competences to act within these conditions.

This discussion illustrates how an institutional perspective on mediatization can enable an analysis of changes in religious authority as a process of interrelated changes on various levels. Following from this discussion, we propose an understanding of mediatization of religion as the processes through which various forms of media (journalism, entertainment, social media, etc.) become prominent producers of religious meanings and experiences at the same time as religious organizations and individuals have to reconsider existing practices and engage with a mediatized environment in attempts to 
reassert their authority under new conditions. On the macro level of relations between institutions, mediatization challenges control by religious leaders and organizations over religious symbols. Mediatization also introduces new conditions regarding the positions and institutional resources from which the authority to speak about religion can be claimed. Such changes cannot be assumed to have direct effects on individual's perceptions and actions, but changes in access to information and interaction with other users through media enable people to assess and respond to religious authorities in new ways. Thus, mediatization of religion is a dynamic process of change where positions and resources for speaking with authority about religion are shaped by the affordances of particular media institutions, at the same time as the influence of media logics can generate new ways for religious organizations and individuals to engage with a mediatized environment.

\section{$7 \quad$ Mediatization of Religion outside the North-Western Context}

In this final section we will address the critique against the mediatization of religion theory concerning whether it can be valid outside of a North-Western religious context (Lynch, 2011, p. 206). By discussing three studies that apply and critique mediatization of religion theory within Islam, Buddhism and New Age, we will develop our argument about how the institutional approach to mediatization presented above may be applicable in other contexts.

Eisenlohr (2017) seeks to reconsider the debate on religion and mediatization beyond Christian North Atlantic contexts in his analysis of two instances of Islamic televangelism in India: the Salafist preacher Zakir Naik of the Islamic Research Foundation and its associated TV channel Peace TV, and the Twelver Shi'ite World Islamic Network associated with Ayatollah Sistani in Najaf, Iraq. Like Herbert (2011), Eisenlohr argues that it is necessary to differentiate between two dimensions of the intersection of media and religion: religion in the public sphere, which relates to interactions between human actors through circulation of religious discourse and images, and religious mediation, which concerns interaction between human and divine or spiritual actors. The degree to which religious practices and institutions become subsumed under institutional media logics (Eisenlohr, 2017, p. 871) in a particular context therefore depends on the character of the interactions between public religion and religious mediation. Eisenlohr further argues that, in contexts outside of Europe and North America, historically established forms of religious mediation can show greater resistance to change induced by media technology. By use of the concept of "domestication", he points to how the use of new media 
technologies becomes shaped by previous forms of religious mediation (Eisenlohr, 2017, p. 873).

Eisenlohr's analysis shows how some dimensions of established patterns of religious mediation, such as the dominance of oral recitations of the Qur'an and learned interpretation of scripture and hadith, persist in a new media format of televised talk shows. At the same time, these patterns undergo a transformation through the adaptation of themes and forms of expression from the talk show, such as references to popular culture, youth culture and consumption and the question-and-answer format. Eisenlohr's study is, we would argue, an example of how an institutional perspective on mediatization of religion can be applied outside of the North-Western European context. Here, mediatization of religion is analyzed by focusing on the interplay between the logic of a particular media institution and the logic of a particular form of religious mediation. The focus on religious mediation - in our interpretation, an institutionalized way of interaction between human beings and divine actors - makes it possible to identify more complex dynamics of religious change. This concerns the differentiation between media-induced transformations on the level of public discourse on religion and on the level of a particular religious tradition, and between more resilient and more adaptive forms of religious mediation that operate on different levels (Eisenlohr, 2017, p. 882).

Grieve, Helland, and Singh (2018) undertake a critical "reconditioning" of the mediatization of religion theory in their study of the digitalization of the Tibetan Buddhist 33rd Kalachakra ceremony, held in Leh, Ladakh, India, in 2014. The authors recognize the idea that, on a macro level, media as an institution influences communication by making "certain actions possible, exclude[s] others and structure[s] the interactions between actor and object" (Hjarvard, 2013, p. 27). However, their main argument concerns whether the claims of the theory would also be valid when applying the theory to a religious tradition with a different understanding of communication than within Protestant Christianity. The concept of "Dharma" used in Tibetan Buddhism refers to a form of communication that seeks to establish a mutually dependent relationship between actors, in order to lessen suffering (duhkha) in the world. By using this understanding of communication as mutual conditioning, Grieve, Helland and Singh find that the ceremony's digitalization actually increased its religious character. The ceremony's goal of mutual conditioning and reducing suffering was enhanced by the digitalization of the local ceremony, which enabled immediacy, initiation into religious core practices, and strengthened community and authority.

Rather than refuting the theory of mediatization of religion, we would argue that this study can be compatible with the institutional perspective presented 
in this article. By emphasizing the communication logic of Tibetan Buddhism, Grieve et al. perform an analysis of the interplay between an institutional religious logic as manifested in a particular time and space and a particular media institution, in this case an interactive ceremony using various forms of digital media technology such as web cameras and chat forum. Their main finding, that this interplay can explain the development rather than the decline of the phenomenon of Tibetan Buddhism in diaspora, is in our understanding in conjunction with the institutional approach to mediatization as a multilevelled, reciprocal process described in this article.

As a final example we will use Kraft's (2017) critical discussion of the validity of the concept of "banal religion" for understanding New Age. Kraft argues that rather than seeing the mixing of elements from various religious sources in contemporary New Age practices as a media-induced form of religion, we should see it as the media picking up and using established New Age "recipes". Again we would argue that this is an example of the dynamic interaction between a particular manifestation of religion as institution and the workings of entertainment media as institution. The bricolage character of contemporary New Age practices need not be seen as media induced, but, as in the case of Eisenlohr's (2017) study, certain formulas or recipes of New Age practices accommodate more easily to the logics of, for example, entertainment media. As such formulas become more wide spread, they can give rise to new conditions where groups or practitioners and leaders within New Age are challenged to reconsider their practices and reassert their authority.

These examples represent valuable critical assessments of the mediatization of religion theory that show the need to develop the understanding of religion, institution, and change within the original theory. They align with arguments by Lövheim (2014), Lundby (2013, p. 197) and Campbell (2017) on approaching the mediatization of religion as a process of dynamic, mutual change between the affordances of various media institutions, and how religious actors with particular values and patterns of social relations use, negotiate, and reshape such affordances. Furthermore, they show the crucial importance of contextualizing the concept of media as institution with regard to historical and political processes in various parts of the world.

While recognizing these insights we maintain, in line with Anthony Giddens' (1990) discussion of reflexive modernization, that the intensified technical mediation since the 1950s enhances certain features across the globe, such as the differentiation and disembedding of practices from local contexts, and the ability for individuals to not only retrieve information but also communicate and interact across borders. As a consequence, religious communities must increasingly adapt to an environment in which information about other 
possible worlds is freely available and often commercially marketed, and individuals have greater possibilities of articulating their concerns. Even though the way that these changes towards increased individualization, reflexivity, and consumer orientation are spelled out will vary considerably within particular contexts, certain trends in religious change will be more pronounced than others across national and cultural contexts.

\section{Summary}

Thirty years after its initiation, the field of research in media, religion and culture faces new challenges. Departing from a critique of a narrow understanding of religion and media as institutions, the field developed a focus on culture and individual agency. In this article, we have argued for a re-engagement with the notion of institutions through new applications of institutional theory and of mediatization of religion theory.

To summarize, we consider an institutional approach to be a relevant tool for analyzing the relation between mediatization and religious change across various levels of analysis. An institutional perspective allows us to understand - rather than ignore - the duality between structure and agency with regard to the enactment of an institution on a societal, organizational and individual level. An understanding of the dynamics or logics of institutions as continuous processes of reflexive sense-making that includes collective and individual agency, and cultural aspects such as material practice, assumptions, values and beliefs, enables an analysis of how the logics or affordances within particular forms of media influence practices, values and relations within a particular manifestation of religion. In this way, an institutional perspective on mediatization of religion is also relevant to religious traditions such as Vodou or New Age, which might appear to have a low degree of institutionalization, precisely because it enables an analysis of how the meaning of religion changes due to the manifold institutional dynamics (media, cultural, political, etc.) that rearticulate the meanings and practices of this religion. Through aiming for a holistic understanding of religious change that includes the interplay between structure and agency at various levels of analysis, i.e. macro, meso, and micro levels, an institutional perspective on mediatization remains an important contribution to, for example, cultural ethnographic approaches that provide rich accounts of particular empirical phenomenon but often lack an analysis of how individual agency is informed by collective norms and resources as well as wider social and cultural transformations. An institutional perspective on mediatization enables an analysis of different forms of mediatized religion 
with regard to the relative influence of other, intersecting, institutional domains in a particular place and time.

Our discussion is prompted by changes in the larger culture and society. A new visibility of conflicts involving religion, with media often working as a structuring intermediary, has evoked new interest in the interplay between religion, media and other cultural and social domains. Thus, we cannot study the interplay between media and religion in isolation. Because media become "social tools" for interactions in almost all domains of society, it is not only in their capacity as audiences or media users that individuals may act in and by the media. Following the institutional perspective to mediatization studies, the challenge for the research field in the future is also to consider a wider scope of ways in which growing contentions involving religion and media relate to agency and social change in social roles and situations within politics, religion, family, education, etc., regarding, for example, issues of immigration, gender, and social injustice.

\section{References}

Asp, K. (1990). Medialisering, Medielogik, Mediekrati. Nordicom Information 1990 (4), pp. 7-12.

Axner, M. (2013). Public Religions in Swedish Media: A Study of Religious Actors on Three Newspaper Debate Pages 2001-2011. Studies in Religion and Society, 11. Uppsala: Acta Universitatis Upsaliensis.

Axelson, T. (2015). Vernacular Meaning Making: Examples of Narrative Impact in Fiction Film Questioning the "Banal" Notion in Mediatization of Religion Theory. Nordicom Review 36 (2), pp. 143-56.

Billig, M. (1995). Banal Nationalism. London: Sage.

Boutros, A. (2011). Gods on the Move: The Mediatization of Vodou. Culture and Religion 12 (2), pp. $185^{-201 .}$

Brubaker, R. (2017). Between Nationalism and Civilizationism: The European Populist Moment in Comparative Perspective. Ethnic and Racial Studies 40 (8), pp. 1191-1226.

Campbell, H. (2007). Who's Got the Power? Religious Authority and the Internet.Journal of Computer-Mediated Communication 12 (3), pp. 1043-1062.

Campbell, H. (2010). When Religion Meets New Media. London: Routledge.

Campbell, H. (2017). Surveying Theoretical Approaches Within Digital Religion Studies. New Media \& Society 19 (1), pp. 15-24.

Christensen, H.R. (2012). Mediatization, Deprivatization, and Vicarious Religion. In: S. Hjarvard and M. Lövheim, eds., Mediatization and Religion: Nordic Perspectives. Gothenburg: Nordicom, pp. 63-78. 
Clark, L.S. (2008). Religion, Philosophy, and Convergence Culture Online: ABC's Lost as a Study of the Processes of Mediatization. Northern Lights 6 (1), pp. 143-163.

Clark, L.S. (2011a). Religion and Authority in a Remix Culture: How a Late Night TV Host Became an Authority on Religion. In: G. Lynch, J. Mitchell and A. Strhan, eds., Religion, Media and Culture: A Reader. London: Taylor and Francis, pp. 111-121.

Clark, L.S. (2011b). Considering Religion and Mediatisation Through a Case Study of J+K's Big Day (The J K Wedding Entrance Dance): A Response to Stig Hjarvard. Culture and Religion 12 (2), pp. 167-184.

Clark, L.S. \& Hoover, S. (1997). At the Intersection of Media, Culture, and Religion: A Bibliographic Essay. In S. Hoover and K. Lundby, eds., Rethinking Media, Religion, and Culture. Thousand Oaks, CA: Sage, pp. ${ }^{15}-36$.

Couldry, N. (2008). Digital Storytelling, Media Research and Democracy: Conceptual Choices and Alternative Futures. In: K. Lundby, ed., Digital Storytelling, Mediatized Stories: Self-representations in New Media. New York, NY: Peter Lang, pp. 41-6o.

Dijck, J.van (2013). The Culture of Connectivity: A Critical History of Social Media. Oxford: Oxford University Press.

DiMaggio, P. \& Powell, W. (1991). Introduction. In: P. J. DiMaggio and W. Powell, eds., The New Institutionalism in Organizational Analysis. Chicago: University of Chicago Press, pp. 1-38.

Eisenlohr, P. (2017). Reconsidering Mediatization of Religion: Islamic Televangelism in India. Media, Culture \& Society 39 (6), pp. 869-884.

Engelstad, F., Larsen, H., Rogstad, J. \& Steen-Johnsen, K. (2017). Introduction: The Public Sphere in Change: Institutional Perspectives on Neo-corporatist Society. In: Engelstad, F., Larsen, H., Rogstad, J. \& Steen-Johnsen, K., eds., Institutional Change in the Public Sphere: Views on the Nordic Model. London and Warsaw: De Gruyter Open, pp. 1-21.

Furseth, I. (2018). Introduction. In: I. Furseth, ed., Religious Complexity in the Public Sphere: Comparing Nordic Countries. Basington: Palgrave MacMillan, pp. 1-29.

Giddens, A. (1990). The Consequences of Modernity. Cambridge: Polity Press.

Grieve, G., Helland, C. \& Singh, R. (2018). Digitalizing Tibet: A Critical Buddhist Reconditioning of Stig Hjarvard's Mediatization Theory. In: K. Radde-Antweiler \& X. Zeiler, eds., Mediatized Religion in Asia: Studies on Digital Media and Religion. Abingdon: Routledge, pp. 139-161.

Herbert, D. (2011). Why Has Religion Gone Public Again? Towards a Theory of Media and Religious Re-publicization. In: G. Lynch, J. Mitchell and A. Strhan, eds., Religion, Media and Culture: A Reader. London: Taylor and Francis, pp. 89-97.

Hepp, A. (2013). Cultures of Mediatization. Cambridge/Malden, MA: Polity Press.

Hepp, A., Hjarvard, S. \& Lundby, K. (2010). Mediatization - Empirical Perspectives: An Introduction to a Special Issue. Communications: The European Journal of Communication Research, 35 (3), pp. 223-228. 
Hjarvard, S. (2006). Religion og Politik i Mediernes Offentlighed. In: L. Christoffersen, ed., Gudebilleder: Ytringsfrihed og Religion i en Globaliseret Verden. København: Tiderne Skifter, pp. 44-71.

Hjarvard, S. (2008). The Mediatization of Religion: A Theory of the Media as Agents of Religious Change. Northern Lights 6 (1), pp. 9-26.

Hjarvard, S. (2011). The Mediatization of Religion: Theorising Religion, Media and Social Change. Culture and Religion 12 (2), pp. 119-135.

Hjarvard, S. (2013). The Mediatization of Culture and Society. London and New York: Routledge.

Hjarvard, S. (2014). From Mediation to Mediatization: The Institutionalization of New Media. In: A. Hepp and F. Krotz, eds., Mediatized Worlds. New York: Palgrave/ Macmillan, pp. 123-139.

Hjarvard, S. (2016). Mediatization and the Changing Authority of Religion. Media, Culture \& Society, 38 (1), pp. 8-17.

Hjarvard, S. \& Lövheim, M., eds. (2012). Mediatization and Religion:Nordic Perspectives. Göteborg: Nordicom.

Hjarvard, S. \& Lundby, K. (2018). Understanding Media Dynamics. In: K. Lundby, ed., Contesting Religion: The Media Dynamics of Cultural Conflicts in Scandinavia. Berlin and Boston: De Gruyter, pp. 51-64.

Hjarvard, S; Mortensen M. \& Eskjær M. (2015). Introduction: Three Dynamics of Mediatized Conflicts. In: M. Eskjær, S. Hjarvard, \& M. Mortensen, eds., The Dynamics of Mediatized Conflicts. New York: Peter Lang, pp. 1-27.

Hjarvard, S. \& Rosenfeldt, M. (2017). Giving Satirical Voice to Religious Conflict: The Potentials of the Cultural Public Sphere. Nordic Journal of Religion and Society 30 (2), pp. 136-152.

Hjelm, T. (2015). Is God Back? Reconsidering the New Visibility of Religion. In:T. Hjelm, ed., Is God Back? Reconsidering the New Visibility of Religion. London: Bloomsbury, pp. 1-16.

Hoover, S. (2002). The Culturalist Turn in Scholarship on Media and Religion. Journal of Media and Religion (1) 1, pp. 25-36.

Hoover, S. (2009). Complexities: The Case of Religious Cultures. In: K. Lundby, ed., $M e-$ diatization: Concept, Changes, Consequences. New York, NY: Peter Lang, pp. 123-138. Hoover, S. \& Lundby, K. (1997). Introduction: Setting the Agenda. In: S. Hoover and K. Lundby, eds., Rethinking Media, Religion and Culture. Thousand Oaks, CA: Sage, pp. 3-14.

Horsfield, P. (2013). The Ecology of Writing and the Shaping of Early Christianity. In: K. Lundby, ed., Religion Across Media: From Early Antiquity to Late Modernity. New York: Peter Lang, pp. 37-53.

Klassen, P. \& Lofton, K. (2013). Material Witnesses: Women and the Mediation of Christianity. In: M. Lövheim, ed., Media, Religion and Gender: Key Issues and New Challenges. London and New York: Routledge, pp. 52-65. 
Kraft, S. (2017). Bad, Banal and Basic: New Age in the Norwegian News Press and Entertainment Media. In: I. Gilhus, S. Kraft and J. Lewis, eds., New Age in Norway. London: Equinox, pp. 65-78.

Lied, L. (2012). Religious Change and Popular Culture: With a Nod to the Mediatization of Religion Debate. In: S. Hjarvard \& M. Lövheim, eds., Mediatization and Religion: Nordic Perspectives. Göteborg: Nordicom, pp. 183-201.

Livingstone, S. (2009). On the Mediation of Everything: ICA Presidential Address 2008. Journal of Communication 59 (1), pp. 1-18.

Lundby, K. (2013). Media and Transformations of Religion. In: K. Lundby, ed., Religion Across Media: From Early Antiquity to Late Modernity. New York: Peter Lang, pp. 185-202.

Lundby, K. (2016). Mediatization and Secularization:Transformations of Public Service Institutions - the Case of Norway. Media, Culture, Society 38 (1), pp. 28-36.

Lundby, K. (2017). Public Religion in Mediatized Transformations. In: F. Engelstad, H. Larsen, J. Rogstad \& K. Steen-Johnsen, eds., Institutional Change in the Public Sphere: Views on the Nordic Model. Berlin: De Gruyter Open, pp. 241-263.

Lundby, K., ed. (2018a). Contesting Religion: The Media Dynamics of Cultural Contexts in Scandinavia. Berlin, Boston: De Gruyter.

Lundby, K. (2018b). Interaction Dynamics in the Mediatization of Religion Thesis. In: K. Lundby, ed., Contesting Religion: The Media Dynamics of Cultural Contexts in Scandinavia. Berlin, Boston: De Gruyter. pp. 299-314.

Lundby, K., Christensen, H. R., Gresaker, A. K., Lövheim, M., Niemelä, K., Sjö, S., Moberg, M. \& Daníelsson, Á. S. (2018). Religion and the Media: Continuity, Complexity, and Mediatization. In: I. Furseth, ed., Religious Complexity in the Public Sphere: Comparing Nordic Countries, Basingstoke: Palgrave MacMillian, pp. 193-249.

Lundmark, E. (2019). "This is the Face of an Atheist": Performing Private Truths in Precarious Publics. Doctoral Thesis, Uppsala: Uppsala University.

Lynch, G. (2011). What Can We Learn from the Mediatisation of Religion Debate? Culture and Religion 12 (2), pp. 203-210.

Lövheim, M. (2011). Mediatisation of Religion: A Critical Appraisal. Culture and Religion 12 (2), pp. 153-166.

Lövheim, M. (2012). A Voice of Their Own: Young Muslim Women, Blogs, and Religion. In: S. Hjarvard \& M. Lövheim, eds., Mediatization and Religion: Nordic Perspectives. Gothenburg: Nordicom, pp. 129-145.

Lövheim, M. (2014). Mediatization and Religion. In: K. Lundby, ed., Mediatization of Communication. Handbooks of Communication Science 21. Berlin and Boston: De Gruyter Mounton, pp. 547-571.

Lövheim, M. (2016). Mediatization: Analyzing Transformations of Religion from a Gender Perspective. Media, Culture \& Society 38 (1), pp. 18-27. 
Lövheim, M. (2017). Religion, Mediatization and "Complementary Learning Processes" in Swedish Editorials. Journal of Religion in Europe 10 (4), pp. 366-383.

Lövheim, M. \& Lied, L. I. (2018). Approaching Contested Religion. In: K. Lundby, ed., Contesting Religion: The Media Dynamics of Cultural Contexts in Scandinavia. Berlin, Boston: De Gruyter, pp. 65-80.

Lövheim, M \& Lynch, G. (2011). The Mediatisation of Religion Debate: An Introduction. Culture and Religion 12 (2), pp. 111-118.

March, J. G. \& Olsen, Johan P. (1989). Rediscovering Institutions: The Organizational Basis of Politics. New York: Free Press.

March, J. G. \& Olsen, Johan P. (2004). The Logic of Appropriateness. ARENA Working Papers 04/og. Oslo: ARENA, Centre for European Studies.

Meyer, B. \& Moors, A. (2006). Introduction. In: B. Meyer and A. Moors, eds., Religion, Media, and the Public Sphere. Bloomington: Indiana University Press, pp. 1-25.

Meyer, B. (2013). Material Mediations and Religious Practices of World-Making. In: K. Lundby, ed., Religion Across Media: From Early Antiquity to Late Modernity. New York: Peter Lang, pp. 1-19.

Moberg, M. (2018). Mediatization and the Technologization of Discourse: Exploring Official Discourse on the Internet and Information and Communications Technology Within the Evangelical Lutheran Church of Finland. New Media \& Society 20 (2), pp. 515-531.

Morgan, D. (2011). Mediation or Mediatisation: The History of Media in the Study of Religion. Culture and Religion 12 (2), pp. 137-152.

Sreberny-Muhammadi, A. and Muhammadi, A. (1994). Small Media, Big Revolution: Communication, Culture, and the Iranian Revolution. Minneapolis, MN: University of Minnesota Press.

Thornton, P H. \& Ocasio, W. (1999). Institutional Logics and the Historical Contingency of Power in Organizations: Executive Succession in the Higher Education Publishing Industry 1958-1999. American Journal of Sociology 105 (3), pp. 801-43.

Walby, S. (2007). Complexity Theory, Systems Theory, and Multiple Intersecting Social Inequalities. Philosophy of the Social Sciences 37 (4), pp. 449-470.

Weber, M. (1978). Economy and Society: An Outline of Interpretive Sociology. Berkeley, CA: University of California Press. 